\title{
On a new reagent for ascertaining the presence of sugar in certain liquids
}

\section{Maumené}

To cite this article: M. Maumené (1850) On a new reagent for ascertaining the presence of sugar in certain liquids, Philosophical Magazine Series 3, 36:245, 482-482, DOI:

$10.1080 / 14786445008646530$

To link to this article: http://dx.doi.org/10.1080/14786445008646530

曲 Published online: 30 Apr 2009.

Submit your article to this journal $₫$

Џ Article views: 2

Q View related articles $₫$ 


\section{ON A NEW RFAGENT FOR ASCERTAINING THE PRESENCE OF SUGaR IN CERTAIN LIQUids. BY M. MAUMENÉ.}

Chemists have indicated several processes for the detection of sugar, even under the singular circumstances of diabetes. Unfortunately no one of these processes is sufficiently simple for adoption in medical practice. The author proposes one by means of a reagent of tissue, which will instantly discover the presence of the smallest quantity of sugar.

The action of chlorine on sugar is very imperfectly known, and the experiments which M. Maumené has performed liave shown numerous inaccuracies in the assertions which have been made by ccle. brated chemists. Thus chlorine acts even on dry sugar; it requires only $212^{\circ} \mathrm{F}$. to excite the reaction; when cold, more time is required. In all cases a brown matter is formed, partly soluble in water, becoming a brilliant black caramel when it is dried. This is obtained by chlorine, and it is easily procured with the chlorides, and especially with the perchlorides.

All sugars act in the same way as cane-sugar with the chlorides; all undergo the dehydratation, the brown-black product of which is the final completion. And this is not all; as may be foreseen, substances, the composition of which is analogous to that of sugar, and which may also be represented by carbon and water, undergo the same kind of alteration: this is the case with lignin, hemp, flax, cotton, paper, starch, fecula, \&c.

From all these facts results a knowledge of the conditions requisite for preparing a substance which has imbibed the reagent proper for discovering the presence of sugar. Strips of white merino answer this purpose; after having soaked it during three or four minutes in an aqueous solution of bichloride of tin, made with 100 parts of the bichloride of commerce and 200 parts of water, the merino is drained, and when dried in a water-bath on a strip of the same stuff, the reagent is prepared. It is to be cut into portions of 7 to 10 centimetres in length and 2 to 3 wide, like common test.papers.

By employing this chlorinated merino, the physician can, without any trouble, determine whether the urine contains an appreciable trace of sugar. It is sufficient to let fall a drop of the urine on the prepared test, and to hold it over red-hot charcual, or the flame of a spirit-lamp, to produce in a minute a very visible black spot. 'The sensibility of this reagent is extreme; ten drops of diabetic urine, added to 100 cubic centimetres of water, form a liquid with which the test is rendered completely brownish-black. Common urine, urea and lithic acid, yield no such discoloration with chloride of tin. - Comptes Rendus, Mars 18, 1850.

\section{FORMATION OF ASPARTIC ACID WITH BIMALATE OF AMMONIA.} BY M. DESSAIGNES.

To M. Piria is due our knowledge of the interesting fact, that asparagin and aspartic acid, submitted to the oxidizing action of nitrous gas, disengage nitrogen and leave a residue of malic acid. $\mathrm{He}$ 